\title{
Effect of plant growth promoting rhizobacteria (PGPR) on the growth of chili habanero pepper (Capsicum chinense Jacq.)
}

\author{
Castillo-Aguilar, Grescencio de la Cruz ${ }^{1}$; Córdova-Gaspar, Alberto ${ }^{1}$; \\ Carrillo-Gastañeda, Guillermo ${ }^{2}$; Ortíz-García, Carlos Fredy ${ }^{3}$; Coh-Méndez, Domingo ${ }^{1}$; \\ Chiquiní-Medina, Ricardo Antonio ${ }^{\text {* }}$ \\ 1 Colegio de Postgraduados, Campus Campeche. Sihochac, Champotón, Mexico. C.P. 24050. \\ 2 Colegio de Postgraduados. Campus Montecillos, Carretera Federal Mexico-Texcoco Km 36.5 Montecillo \\ Texcoco, Edo. de México. \\ 3 Colegio de Postgraduados. Campus Tabasco, H. Cárdenas, Tabasco, México. \\ 4 Tecnológico Nacional de México/Instituto Tecnológico de Chiná. Campeche, Campeche, México. C.P. \\ 24520. \\ * Corresponding author: ricardochiquini@yahoo.com.mx
}

Citation: Castillo-Aguilar, C. de la C., Córdova-Gaspar, A., CarrilloCastañeda, G., Ortíz-García, C. F., Coh-Méndez, D., \& Chiquiní-Medina, R. A. (2021). Effect of plant growth promoting rhizobacteria (PGPR) on the growth of habanero pepper (Capsicum chinense Jacq.). Agro Productividad. https://doi.org/10.32854/agrop. v14il1.1690

Editor in Ghief: Dr. Jorge Cadena Iñiguez

Received: March 14, 2021. Accepted: October 19, 2021. Published on-line: November 30, 2021.

This work is licensed under a Creative Commons Attribution-NonCommercial 4.0 International license.

\begin{abstract}
Objective: To evaluate the effect of plant growth promoting rhizobacteria (PGPR) on the growth and production of habanero pepper (Capsicum chinense Jacq.).

Design/Methodology/Approach: Twelve strains of PGPR were evaluated in habanero pepper seeds of the orange variety. The species of PGPR were Rhizobium leguminosarum: (CP Méx 46), Pseudomonas spp: (P. fluorescens, C2, A7, A9, A9m, Avm); Azospirillum, (Sp7, Sp 59, UAP 40, UAP154), plus a control treatment, giving a total of 13 treatments. The study variables were seedling emergence (SE), plant height $(\mathrm{PH})$, white fruit incidence (WFI), virotic plants (VP), days to flowering (DF) and fresh fruit yield (FFY). The experimental design was random blocks with four repetitions.

Results: An effect on the growth of habanero pepper from PGPRs was found in all the variables studied. Seedling emergence and their height was favored by strains Sp9 (84.16\%) and A7 (73.44). The number of white flies decreased with the inoculation of CP Méx 46, while the incidence of virosis decreased in plants inoculated with SP9 (32.00\%). The highest yield of fresh fruit was found in plants with the strain AVM with $16636 \mathrm{~kg} \mathrm{ha}^{-1}$. Findings/Conclusions: The effect of inoculation with PGPR is in function of the strain used and the study variable, growth stage and development stage of the habanero pepper plant.
\end{abstract}

Keywords: Inoculation, Rhizobium, Pseudomonas spp, Azospirillum.

\section{INTRODUCTION}

Habanero pepper (Capsicum chinense Jacq.) is one of the most important crops of the Yucatan Peninsula in Mexico. The average surface cultivated annually is 700 ha; however, it has increased in various states in Mexico to cover the national and international demand. An ecologically acceptable alternative to increase the crop's yield is the inoculation with growth promoting microorganisms, called biostimulants or biofertilizers (Compant et al., 2010). 
One of these microorganisms is plant growth promoting rhizobacteria (PGPR). Rhizobacteria exert beneficial effects on the plants through direct and indirect mechanisms, or a combination of both (Parray et al., 2016). Direct mechanisms happen when the bacteria synthesize metabolites that ease or increase the availability of nutritional elements, required for their metabolism and nutritional process (Gómez-Luna et al., 2012). Among the direct mechanisms, the following stand out: nitrogen fixation $(\mathrm{N})$; synthesis of plant hormones, vitamins and enzymes, solubilization of phosphorus $(\mathrm{P})$ (Esquivel-Cote et al., 2013), while the indirect mechanisms are characterized by the PGPR causing the decrease or elimination of plant pathogen microorganisms, whether through the production of antimicrobial substances or antibiotics, lithic enzymes or a combination of these; from competition of nutrients or space in the ecological niche (Esquivel-Cote et al., 2013). According to Constantino et al. (2008), the vegetative growth of plants and the fruit yield of Capsicum chinense were higher when inoculated with A. brasilense, Azotobacter chroococum and Rhizophagus spp. than in plants without inoculation. For their part, Reyes-Ramírez et al. (2014), in their evaluations with three strains of rhizobacteria in habanero pepper plants treated with Pseudomonas found greater height of the plant, stalk diameter and total dry biomass than the control plants 120 (ddt).

They also found that the yield was higher (899.84 g per plant) and the fruits had greater length, diameter and weight, concluding that the inoculation when transplanting with Pseudomonas spp. to habanero pepper plants increased their growth and the size of the fruit. In collections and evaluations of rhizobacteria strains evaluated in poblano chili pepper plants (Capsicum annuum), an increase of $20 \%$ was found in the weight of the aerial part of the plant, concluding that the rhizobacteria strains can be used to increase the quality of poblano chili seedlings, which could guarantee a better establishment and health of these in the field (González-Mancilla et al., 2017). Complementary studies in tomato and pepper point to the use of rhizobacteria of the genus Bacillus spp. which increased the percentage of germination of pepper seeds in 7\% and the biomass from 16 to 37\% (Luna-Martínez et al., 2013). In this context, the present study evaluated the effect of different experimental PGPR strains on the growth of habanero pepper (Capsicum chinense Jacq.).

\section{MATERIALS AND METHODS}

The experiment was conducted in Chiná, Campeche, Mexico (194 $45^{\prime} 18^{\prime \prime} \mathrm{N}$ and $90^{\circ}$ 26 ' 23" W). The orange variety of habanero chili pepper was used. Twelve experimental strains of plant growth promoting rhizobacteria (PGPR) were evaluated: CP Méx 46 (Rhizobium leguminosarum), P. fluorescens, C2 (P. fluorescens), P. putida, A7 (Pseudomonas sp.), A9 (Pseudomonas sp.), A9m (Pseudomonas sp.), Avm (Pseudomonas sp.), Sp7 (Azospirillum brasilensis), Sp 59 (Azospirillum brasilensis), UAP 40 (Azospirillum brasilensis), and UAP154 (Azospirillum brasilensis).

The chili seeds were inoculated with bacteria suspensions of each strain evaluated with a bacterial suspension volume of $2.5 \mathrm{~mL}$ applied to each lot of seeds $\left(10^{9}\right.$ cells per milliliter of suspension). Once the habanero pepper seeds were inoculated, they were sown manually in polystyrene trays with 200 cavities, depositing one seed per cavity at a depth of one centimeter. 
The substrate used was Canadian peat $\operatorname{moss}^{\mathrm{TM}}$. Ten days after sowing (DAS) the emergence of the seedlings began, and the trays were placed in seed banks of a rustic greenhouse. The irrigation was applied according to the needs of the plant, and irrigating once daily was enough. Derosa ${ }^{\circledR} 1+$ Previcur ${ }^{\circledR}$ at a dose of $1.0 \mathrm{~mL} \mathrm{~L}^{-1}$ were applied, respectively. Raizal ${ }^{\circledR} 0.5 \mathrm{~g} \mathrm{~L}^{-1}$ of water was applied in later irrigation to promote the rooting of the seedling. Fertilization was carried out by the leaf using the formula 20-30-10 (N-P-K), giving on average two applications per week at a rate of $2 \mathrm{~g} \mathrm{~L}^{-1}$ of water.

Transplant was conducted at 60 DAS. The distances between plants were $50 \mathrm{~cm}$ and $1.5 \mathrm{~m}$ between furrows. In the field, habanero pepper plants were subjected to the agronomic management in fertigation recommended by Soria et al. (2002). The experimental unit consisted of three furrows $10 \mathrm{~m}$ long and $1.5 \mathrm{~m}$ wide, considering as a useful plot the central furrow constituted by 21 plants. The study variables were the seedling emergence (SE), which was done through visual counting of the sowing substrate expressed in percentage at 10 DAS; plant height $(\mathrm{PH})$ prior to transplant, days to flowering, plants with virosis (PV) and total fresh fruit yield (FFY). A completely random block experimental design with four repetitions was used. The treatments were the 12 strains of rhizobacteria inoculated on habanero chili seeds and a control treatment without inoculation. The data obtained were subjected to a variance analysis and Tukey's means comparison test $(\mathrm{P} \leq 0.05)$, through the statistical analysis software SAS (Statistical Analysis System Institute).

\section{RESULTS AND DISGUSSION}

\section{Plant emergence}

The effect of the rhizobacteria on the emergence of habanero chili seedlings was variable. The two best treatments were the non-inoculation of seeds, with 84.36 plants emerged at 10 DAS, and the effect of strain Sp 59 (Azospirrillum spp.) with 84.16 plants (Table 1). This effect is barely within the percentage of emerged plants necessary for the commercial production of habanero pepper plants in trays with $80 \%$; therefore, the impact of PGPRs was not clear for the conditions of study. Lagunas et al. (2001) reported that the inoculation with Bacillus firmus increased their germination in $6.0 \%$, effect of similar magnitude to that found in this assay. Similar results have shown that inoculation with Bacillus spp. in poblano chili (Capsicum annuum) promoted increments in germination of $7 \%$ (Jalili et al., 2009). This improvement in germination can be explained by the reduction of the levels of ethylene in the seed and the increase of indole-3-acetic acid, stimulating the cell division and an increase in germination.

\section{Plant height}

The plant height of habanero chili at the time of transplant presented more evident effects regarding the rhizobacterial inoculation, which is why the inoculated plants presented a higher response to inoculation and therefore a greater plant height than those not inoculated (Table 1). The results showed that the strains with greatest effect were a A7 (Azospirillum) and Avm (Pseudomonas) with plants of 23.44 and $20.8 \mathrm{~cm}$ height, superior to those found at treatment without inoculation $(14.02 \mathrm{~cm})$. 
Table 1. Seedling germination and plant height at plant transplant of Capsicum chinense Jacq. inoculated with PGPR.

\begin{tabular}{|c|c|c|c|}
\hline $\begin{array}{c}\text { Treatment } \\
\text { (strain) }\end{array}$ & Species & Germination & $\begin{array}{c}\text { Heigth } \\
(\text { cm) }\end{array}$ \\
\hline Cp Mex 46 & (Rizobium leguminozarum by phaseoli) & $79.34 \mathrm{~d}$ & $16.95 \mathrm{def}$ \\
\hline P. fluorescens & P. fluorescens & $72.34 \mathrm{~b}$ & $14.38 \mathrm{ab}$ \\
\hline $\mathrm{C} 2$ & (P. fluorescens) & $78.30 \mathrm{~d}$ & $18.33 \mathrm{f}$ \\
\hline P. putida & (Pseudomonas putida) & $76.14 \mathrm{c}$ & $15.69 \mathrm{bcd}$ \\
\hline A7 & (Pseudomonas sp. cepa 7) & $74.06 \mathrm{~b}$ & $23.44 \mathrm{i}$ \\
\hline A9 & (Pseudomonas sp. cepa 9) & $74.14 \mathrm{~b}$ & $14.28 \mathrm{ab}$ \\
\hline $\mathrm{A} 9 \mathrm{~m}$ & (Pseudomonas sp. cepa A9m) & $81.34 \mathrm{e}$ & 17.12 ef \\
\hline Avm & (Pseudomonas sp. cepa Avm) & $74.06 \mathrm{~b}$ & $20.8 \mathrm{~h}$ \\
\hline Sp 7 & Azospirrillum brasilensis cepa Sp7 & $76.47 \mathrm{c}$ & $17.33 \mathrm{ef}$ \\
\hline Sp 59 & Azospirrillum brasilensis cepa Sp59 & $84.16 \mathrm{f}$ & $15.05 \mathrm{abc}$ \\
\hline UAP 40 & Azospirrillum brasilensis cepa UAP40 & $79.06 \mathrm{~d}$ & 16.02 cde \\
\hline UAP 154 & Azospirrillum brasilensis cepa Sp154 & $81.32 \mathrm{e}$ & $15.43 \mathrm{abc}$ \\
\hline Not inoculated & & $84.36 \mathrm{f}$ & $14.02 \mathrm{a}$ \\
\hline DMS & & 1.16 & 1.39 \\
\hline
\end{tabular}

Treatments with the same letter are statistically equal (Tukey $\alpha=0.05)$.

This increase in the growth can be translated into more vigorous plants, better nourished than those that use less time to obtain the adequate height of transplant $(12 \mathrm{~cm})$. On average, the plants inoculated with strains of rhizobacteria presented a height at harvest of 22.07 compared to the $14.02 \mathrm{~cm}$ obtained in plants without inoculating, which implies less time in the production of plants without devaluing their quality. These results can be compared to those obtained by Castillo et al., (2017) in their evaluations with different strains of experimental rhizobacteria in the production of habanero chili plants, who found that inoculation with rhizobacteria in habanero chili with rhizobacteria strains BSP1.1, R44 and P61 promoted a significant increase in the height of plants in tray (39, 35 and $25 \%$, respectively), compared to the control plants. It is important to consider that colonization of rhizobacteria requires time and happens only when there is compatibility between the microorganisms and the intrinsic factors of the plant, such as root exudates (Khalid et al., 2004, Trivedi et al., 2012). In addition, it is necessary to consider the existence of other physiological mechanisms promoted by PGPRs such as better water absorption and efficient use of mineral elements (Egamberdiyeva, 2007), production of indole-3-acetic acid (IAA), which promotes root or vegetative development (García et al., 2010), with the consequent reduction of ethylene in addition to a better use of the nutrients in the growth substrate (Husen et al., 2011).

\section{Incidence of white fly}

The plants inoculated with the strains CP Mex 46, P. fluorescens and C2 (Pseudomonas) presented lower incidence of white fly (Table 2), showing on average 17, 16.5 and 17 insects per trap, respectively. The variation of the results found can be attributed to the 
effects of each strain of rhizobacteria in the study and the rhizosphere interaction in the cultivation site, as well as the physical and chemical conditions of the soil. With relation to this variable, authors such as Chiquito (2002) in jalapeño pepper and tomato crops, found that plants inoculated with rhizobacteria presented low incidence of white fly, attributing that to the presence of siderophores, hydrogen cyanide, and salicylate in plants. The low incidence of white fly can also be attributed to the suppression of substances that attract the white fly in inoculated plants (Zendher et al., (1997). According to Martínez and Carrillo (1990) the genera Pseudomonas, Rhizobium and Azotobacter are the ones that activate most the synthesis of siderophores.

\section{Number of virotic plants}

The number of virotic plants from the effect of inoculation with rhizobacteria varied significantly (Table 2). On average, the percentage of virotic plants was lower in plants with PGPR (58.88\%) compared to the plants not inoculated (62.25\%). The results showed that the strains Sp9 and Avm presented lower percentage of virotic plants, 32\% and 34\%, respectively, significantly lower incidence than the control treatment (62.25\%).

These percentages could be favored by the intense precipitations of the prior agricultural cycle, which abated drastically the populations of white fly in the field, giving as a result a reduction of the transmission of virosis. It should be considered that the resistance induced is associated with the capacity of PGPRs to promote the growth of plants and protect them against the attack from pathogens. The effect of repelling the white fly or keeping the plant from becoming a host can be attributed to the induced resistance provoked by a large variety of microorganisms such as Pseudomonas fluorescens and Pseudomonas putida,

Table 2. Incidence of white fly (Bemisia tabasi), virotic plants, and day to flowering Capsicum chinense Jacq. plants inoculated with PGPR.

\begin{tabular}{|c|c|c|c|c|}
\hline $\begin{array}{c}\text { Treatment } \\
\text { (strain) }\end{array}$ & Species & $\begin{array}{c}\text { Whitefly } \\
\text { incidence }(\mathrm{PL})\end{array}$ & $\begin{array}{c}\text { Virotic plants } \\
(\%)\end{array}$ & $\begin{array}{c}\text { Flowering } \\
\text { (days) }\end{array}$ \\
\hline Cp Mex 46 & (Rizobium leguminozarum by phaseoli) & $17.00 \mathrm{a}$ & $54.67 \mathrm{~d}$ & $62.27 \mathrm{~d}$ \\
\hline P. fluorescens & P. fluorescens & $16.75 \mathrm{a}$ & $68.25 \mathrm{~h}$ & $58.24 \mathrm{a}$ \\
\hline $\mathrm{C} 2$ & (P. fluorescens) & $17.25 \mathrm{a}$ & $60.67 \mathrm{df}$ & $63.24 \mathrm{e}$ \\
\hline P. putida & (Pseudomonas putida) & $19.75 \mathrm{ab}$ & $64.05 \mathrm{~g}$ & $62.72 \mathrm{de}$ \\
\hline A7 & (Pseudomonas sp. cepa 7) & $30.50 \mathrm{~b}$ & $60.67 \mathrm{df}$ & $58.70 \mathrm{ab}$ \\
\hline A9 & (Pseudomonas sp. cepa 9) & $24.00 \mathrm{~b}$ & $61.37 \mathrm{f}$ & $58.72 \mathrm{ab}$ \\
\hline A9m & (Pseudomonas sp. cepa A9m) & $38.50 \mathrm{c}$ & $69.00 \mathrm{~h}$ & $59.27 \mathrm{~b}$ \\
\hline Avm & (Pseudomonas sp. cepa Avm) & $29.00 \mathrm{~b}$ & $34.62 \mathrm{~b}$ & $58.11 \mathrm{a}$ \\
\hline Sp 7 & Azospirrillum brasilensis cepa $\mathrm{Sp} 7$ & $19.50 \mathrm{ab}$ & $58.57 \mathrm{f}$ & $58.76 \mathrm{ab}$ \\
\hline Sp 59 & Azospirrillum brasilensis cepa Sp59 & $21.00 \mathrm{ab}$ & $32.00 \mathrm{a}$ & $59.24 b$ \\
\hline UAP 40 & Azospirrillum brasilensis cepa UAP40 & $34.75 \mathrm{~b}$ & $40.35 \mathrm{c}$ & $58.29 \mathrm{a}$ \\
\hline UAP 154 & Azospirrillum brasilensis cepa Sp154 & $38.50 \mathrm{c}$ & $62.25 \mathrm{fg}$ & $58.24 \mathrm{a}$ \\
\hline Not inoculated & & $38.50 \mathrm{c}$ & $89.30 \mathrm{i}$ & $61.05 \mathrm{c}$ \\
\hline DMS & & 3.51 & 2.35 & 0.85 \\
\hline
\end{tabular}

Treatments with the same letter are statistically equal (Tukey $\alpha=0.05)$. 
species used in this study, which could produce various metabolites as a defense system, among which the following stand out: AS, lipopolysaccharides (LPS), siderophores, cyclic lipopeptides, 2,4-diacetylphloroglucinol, homoserine lactones, and volatile compounds such as acetoin and 2,3-butanediol (Molina-Romero et al., 2015). Also, it is important to consider that the plants have genes that codify to generate chemical defense mechanisms against the attack of pathogenic organisms, whether by decreasing or impeding such an attack. This biological phenomenon has been called systemic resistance (Gómez and Reis, 2011).

\section{Days to flowering}

The effect of inoculation with PGPR on 50\% of the flowering of habanero chili plants was variable, and the following strains were found to be outstanding: Avm (Pseudomonas sp.) with 58.11 days, followed by UAP 154Y P. fluorescens with 58.24 days for both, less time than that found with the control treatment of 61.05 days.

The difference of 2.94 days between AVM and the control seems small, although in three days the prices of the fruit of the habanero chili can vary drastically. The results found could be influenced by the management of the crop, fertilization, water availability, temperature, presence of diseases, or some pest insect, conditions that could induce the reproductive stage earlier. With relation to this, Molina-Romero et al. (2015) established that PGPRs have the capacity to produce growth promoting substances (auxins; gibberellins; and cytokinins), and with this to promote the floral induction, floral differentiation, and floral development, processes that entail metabolic changes in the plant, such as gibberellin production (Yuri et al., 2002).

\section{Fresh fruit yield}

The habanero chili pepper yield was favored in different magnitude from rhizobacterial inoculation. The best treatment found was inoculation with the strain Avm (Pseudomonas spp.) with average yield of $16636.30 \mathrm{~kg} \mathrm{ha}^{-1}$, compared to the treatment without inoculating with a yield of $12554.80 \mathrm{~kg} \mathrm{ha}^{-1}$ with a difference of $4081.50 \mathrm{~kg} \mathrm{ha}^{-1}$ (Figure 1).

Recent studies with habanero chili in greenhouse conditions inoculated with different strains of rhizobacteria showed that Pseudomonas spp. induced a significant difference in fruit yield compared to the control treatment of $899.84 \mathrm{~g}$ per planta. Rini and Sulochiana (2006) documented the significantly higher growth and yield of the C. annuum plants inoculated with Pseudomonas fluorescens compared to the control without inoculating. For their part, Constantino et al. (2008) observed a higher growth and yield in the Capsicum chinense plants treated with Azospirillum brasilense and a consortium of Rhizophagus spp. compared to plants not inoculated.

Authors such as Reyes-Ramírez et al. (2014) found an increase in habanero chili in the fruit yield and number of fruits $(\mathrm{p} \leq 0.05)$ from inoculation with Pseudomonas fluorescens. This effect on the fresh fruit yield of the chili has possibly been observed in different plant species such as tomato from inoculation with Bacillus spp., Aeromonas spp. and Pseudomonas lini, plus an effect of the rhizobacteria-substrate interaction. 


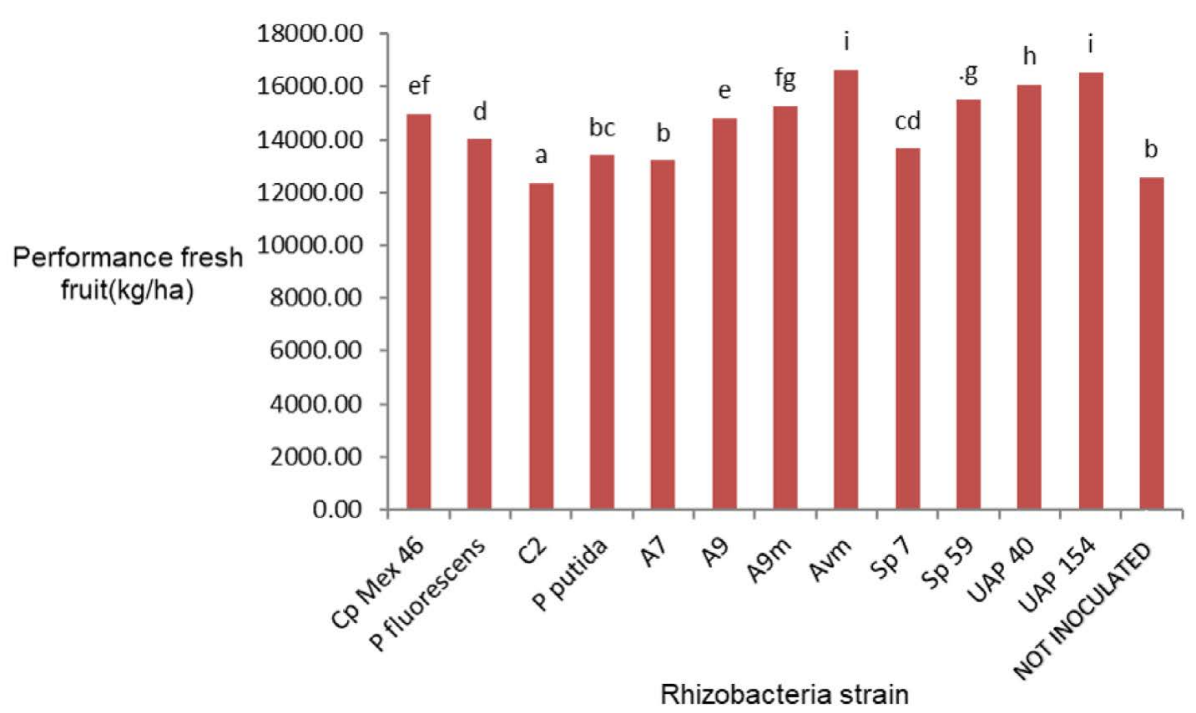

Figure 1. Yield by treatment of fresh fruit of habanero pepper. Treatments with the same letter are statistically the same (Tukey $\alpha=0,05)$. DMS $=392.04$

\section{CONGLUSIONS}

The results in this study indicated that there is a promotion of the growth of the habanero chili plant from the effect of the inoculation with rhizobacteria with variation due to the strain and the variable or the state of development of the plant. It is concluded that the Pseudomonas genus is potentially usable in the production of habanero chili seedling and fruit.

\section{REFERENGES}

Castillo-Aguilar C de la C, J J Zúñiga-Aguilar, A A Guzmán-Antonio, R Garuña.2017. La inoculación von PGPR mejora el crecimiento, 1 absorción de nutrientes y parámetros fisiológicos de las plantas de capsicum chinense. фyton 9457 (86): 199-204.

Compant, S. C. Clement, and A. Sessitsch. 2010. Plant growthpromoting bacteria in the rhizo- and endosphere of plants: their role, colonization, mechanisms involved and prospect for utilization. Soil Biol. Biochem. 42: 669-678.

Constantino M., R. Gómez-Álvarez, J. D. Álvarez-Solís, V. Geissen, E. Huerta, and E. Barba. 2008. Effect of inoculation with rhizobacteria and arbuscular micorrhizal fungi on growth and yield of Capsicum chinense Jacquin. J. Agric. Rural Develop. Trop. Subtrop. 109: 169-180.

Chiquito G RG. 2002. Impacto de PGPR en la uniformidad, vigor y condición fitosanitaria de chile (Capsicum annum L) y jitomate (Licopersicon esculentjum Mill) determinado al momento del trasplante. Tesis de Maestría en Ciencias, Colegio de Postgraduados. Montecillo, Texcoco, Edo. De México.

Egamberdiyeva, D. (2007). The effect of plant growth promoting bacteria on growth and nutrient uptake of maize in two different soils. Applied Soil Ecology 36: 184-189.

Esquivel-Cote, R., Gavilanes-Ruiz, M., Cruz-Ortega, R. y Huante, P. (2013). Importancia agrobiotecnológica de la enzima ACG desaminasa en rizobacterias, una revisión. Revista Fitotecnia Mexicana, 36(3), 251258.

García F, H Muñoz, C Carreño, G Mendoza (2010) Caracterización de cepas nativas de Azospirillum spp. y su efecto en el desarrollo de Oryza sativa L. "arroz" en Lambayeque. Sci. Agropec. 1:107- 116

Gómez-Luna, B. E., Hernández-Morales, A., HerreraMéndez, C. H., Arroyo- Figueroa, G., VargasRodríguez, L. y Olalde-Portugal, V. (2012). Aislamiento de bacterias promotoras del crecimiento de la rizósfera de plantas de guayaba (Psidium guajava). Ra Ximhai, 8(3), 97-102.

Gómez, D. E. y Reis, E. M. (2011). Inductores abióticos de resistencia contra fitopatógenos. Química Viva, 10(1), 6-17. 
González- Mancilla A, J J Almaraz- Suárez, R Ferrera-Cerratol, M P Rodríguez- Guzmán, O R TaboadaGaytán, A Trinidad-Santos, A Alarcón, R I Arteaga-Garibay. 2017. Caracterización y selección de rizobacterias promotoras de crecimiento en plántulas de chile poblano (Capsicum annuum L.). Rev. Int. Contam. Ambie. 33(3) 463-474.

Husen E, A T Wahyudi, A S Gianto (2011). Soybean response to 1-aminociclopropano-1-carboxylate deaminase-producing Pseudomonas under field soil conditions. Amer. J. Agric. Biol. Sci. 6:273-278.

Jalili F, K Khavazi, E Pazira, A Nejati, H A Rahmani, H R Sadaghiani, M Miransari (2009) Isolation and characterization of ACC deaminase-producing fluorescent pseudomonads, to alleviate salinity stress on canola (Brassica napus L.) growth. J. Plant Physiol. 166:667-674.

Khalid, A., S. Tahir, M. Arshad \& Z.A. Zahir (2004). Relative efficiency of rhizobacteria for auxin biosynthesis in rhizosphere vs. non-rhizosphere soil. Australian Journal of Soil Research 42: 921-926.

Lagunas L J, M E Zavaleta, K S Osada, O S Aranda, R I Luna, H H Vaquera (2001). Bacillus firmus como agente de control biológico de Phytophthora capsici Leo. en jitomate (Lycopersicon esculentum Mill.). Rev. Mex. Fitopat. 19:57-65.

Luna-Martínez L, R A Martínez-Pacheco, M hernández Iturriaga, S M Arvizu-Medrano, J R PachecoAguilar. 2013. caracterización de rizobacterias aisladas de tomate y su efecto en el crecimiento de tomate y pimiento. Rev. Fitotec. Mex. Vol. 36 (1): 63-69.

Martínez G B, G Carrillo-Castañeda. 1990. Estudio sobre el efecto de Pseudomonas fluorescems en plantas de Phaseolus vulgaris L. Agrociencia 3:127-139

Molina-Romero, D., Bustillos-Cristales, M. R., Rodríguezandrade, O. y Elizabeth, Y. (2015). Mecanismos de fitoestimulación por rizobacterias, aislamientos en América y potencial biotecnológico. Revista de La DES Ciencias Biológico Agropecuarias, 17(2), 24-34.

Parray, J. A., Jan, S., Kamili, A. N., Qadri, R. A., Egamberdieva, D. \& Ahmad, P. (2016). Current Perspectives on Plant Growth-Promoting Rhizobacteria. Journal of Plant Growth Regulation, 35(3), 877-902. doi:10.1007/s00344-016-9583-4.

Reyes-Ramirez A, M López arcos, E Ruiz-Sánchez, L latournerie-Moreno, A Pérez-Gutierrez, M G LozanoContresras, M Zavala-León. 2014. Efectifidad de inoculantes microbianosen el crecimiento y productividad de chile habanero (Capsicun chinense). Agrociencia 48:285-294.

SAS Institute Inc. 2004. SAS/STAT User's guide, Version 9.1. SAS Institute. Cary, NC.

Soria F. M., A. Trejo, J. Tun, R. Saldívar (2002). Paquete tecnológico para la producción de chile habanero (Capsicum chinense Jacq.), Secretaría de Educación Pública/ SEIT/Instituto Tecnológico Agropecuario de Conkal, Yucatán. 21p.

Trivedi, P., A. Pandey, and L. M. Palni. 2012. Bacterial inoculants for field applicactions under mountain ecosystems: present initiatives and future prospects. In: Maheshwari, D. K. (ed). Bacteria in Agrobiolog: Plant Probiotics. Springer-Verlag. pp: 15-44.

Yuri, J., Lobos, G. y Lepe, V. 2002, sept. Pomáceas. Boletín técnico. Universidad de Talca. 2 (5): 1-4.

Zehnder G, J KJloepper, G yan, G wel. 1997. Induction of systemic resistance in cucumber against cuucumber beetles by plant growth promoting rhizobacteria. J Econom.Entomology 89:510-514. 